\title{
Demandas da Enfermagem, de décadas, se sobressaem no enfrentamento à Pandemia COVID-19
}

\author{
Simone Aparecida Peruzzo
}

\section{RESUMO}

O enfrentamento da pandemia de COVID-19 está expondo de forma excepcional as demandas históricas da Enfermagem em relação às más condições de trabalho, a falta qualiquantitativa dos Equipamentos de Proteção Individual e o subdimensionamento da equipe de enfermagem. Entre outras lutas defendidas pelas organizações da profissão, que aguardam há mais de duas décadas, a devida aprovação de Projetos de Lei pelo congresso nacional. O que pensar quando determinada autoridade afirma que nossas reivindicações não podem ser atendidas porque somos muitos, se comparados ao quantitativo de outras profissões? Sentimentos como decepção, desvalorização, insensatez, incoerência, discriminação e o desconhecimento da natureza da nossa profissão, colaboram para a incredulidade. É hora de a sociedade apoiar a categoria perante esses desafios, reconhecendo a especificidade da profissão e o protagonismo que a Enfermagem exerce, oferecendo a ela condições de consolidar a prática social com qualidade e segurança.

${ }^{1}$ Mestre em Enfermagem pela UFSC, Presidente do Coren/PR, Curitiba,PR

\section{Como citar esse artigo:}

Peruzzo SA. Demandas da Enfermagem, de décadas, se sobressaem no enfrentamento à Pandemia COVID-19. Advances in Nursing and Health [Internet]. 2020; 2(2): 8-10. 
O enfrentamento da pandemia de COVID-19 está expondo, de forma excepcional, as demandas históricas da Enfermagem quanto às más condições de trabalho, à falta qualiquantitativa dos Equipamentos de Proteção Individual (EPI) e ao subdimensionamento da equipe de enfermagem, entre outras lutas defendidas pelas organizações da enfermagem que aguardam, há mais de duas décadas, a devida aprovação de Projetos de Lei pelo congresso nacional.

A argumentação apontada pela maior pesquisa realizada na América Latina, ocorrida em 2015 e patrocinada pelo Conselho Federal de Enfermagem (Cofen), Organização Panamericana de Saúde (OPAS) e Fundação Oswaldo Cruz (Fiocruz), traçou o perfil profissional dos Enfermeiros, Técnicos e Auxiliares de Enfermagem e traz a invisibilidade social a que a categoria é submetida como fator capaz de gerar descontentamento, frustração e evasão, mediante a falta de leis que regulamentem a jornada de trabalho, adequado percentual de insalubridade, piso salarial, aposentadoria especial, dimensionamento apropriado da equipe de enfermagem, espaço digno para o descanso entre plantões previstos por lei e capacitação permanente. Condições essas que outras profissões, inclusive mais novas, já conquistaram.

O que pensar quando determinada autoridade afirma que nossas reivindicações não podem ser atendidas porque somos muitos, se comparados ao quantitativo de outras profissões? Sentimentos como, decepção, desvalorização, insensatez, incoerência, discriminação e o desconhecimento da natureza da nossa profissão, colaboram para a incredulidade.

Desgaste físico e mental, doenças ocupacionais, violência institucional, psicológica e física, afastamentos médicos por longos períodos, justificados comumente por estresse ou depressão, além da real necessidade de manter, no mínimo, dois vínculos empregatícios, compõem o cotidiano da categoria atuante nos diferentes serviços de saúde. O conjunto desses fatores certamente torna os pacientes e os trabalhadores vulneráveis.

A projeção da Organização Mundial de Saúde (OMS) é que faltam, no mundo, seis milhões de enfermeiros para atender às necessidades de assistência à saúde da população. 
Em pleno 2020, segundo o diretor da OMS, Tedros Adhanon Ghebreyesus, "as enfermeiras são a espinha dorsal de qualquer sistema de saúde", afirmação essa divulgada em texto oficial da entidade, no Dia Mundial da Saúde, comemorado em 7 de abril deste ano. A mesma organização também definiu 2020 como sendo "O Ano da Enfermagem", período em que a categoria, comumente vulnerável, é colocada à prova ante um cenário de batalha delineado pela COVID19. (1)

No Paraná, são mais de 105 mil profissionais inscritos no Conselho de Enfermagem e, no Brasil, são em torno de 2,3 milhões de profissionais da área, um verdadeiro exército composto majoritariamente por mulheres enfermeiras, técnicas e auxiliares de enfermagem. Este contingente de trabalhadoras não é suficiente para atender às demandas que a pandemia exige. Basta ver a necessidade de convocar formandos, estudantes e trabalhadores que não atuavam na profissão, para assumir ou mesmo substituir colegas contaminados pela COVID19, nesse front.

O alerta da OMS, da Organização das Nações Unidas (ONU), com a Campanha Nursing Now, e do Conselho Internacional de
Enfermeiros joga luz ao trabalho incansável das organizações da Enfermagem, que lutam, há décadas, para o reconhecimento da natureza e responsabilidade da profissão, buscando melhores condições de trabalho e remuneração.

$$
\text { É hora de a sociedade apoiar a }
$$
categoria perante esses desafios, reconhecendo a especificidade da profissão e o protagonismo que a Enfermagem exerce, oferecendo a ela condições de consolidar a prática social com qualidade e segurança. Investir na Enfermagem é investir e proteger a vida da sociedade a que pertencemos.

\section{REFERÊNCIAS}

1. Organização Mundial da Saúde. Relatório sobre a situação mundial da enfermagem 2020. [Internet]. 2020 [cited 2020 June 10]. Available from: https://www.who.int/publications/i/item/nursi ng-report-2020 